\section{Conclusion}

To conclude, assessing language skills is an important component of the teaching and learning process at the tertiary level of education. In case the language tests are developed for the admission purposes, then norm-referenced assessment might be conducted. For achieving classroom goals, criterionreferenced assessment, which measures learners' knowledge and skills against a set of specified criteria, is recommended. University lecturers should devise scoring scales, which allow measuring language tasks as a whole (i.e. holistically) or assessing every criterion provided for the oral or written assignment separately (i.e. analytically). Assessing students' language skills in a proper way will ensure consistency in the teaching and learning process of the higher educational institutions and guarantee quality of education in the country.

\section{References}

1.Alexander O., Argent S., Spencer J. EAP Essentials: A Teacher's guide to Principles and Practice. Reading: Garnet Publishing Ltd.; 2008.

2.Biggs J., Tang C. Teaching for Quality Learning at University. $4^{\text {th }}$ ed. Maidenhead: Open University Press; 2011.

3.Brown H.D. Language Assessment: Principles and Classroom Practices. New York: Pearson ESL; 2003.

4.Bruce I. Theory and Concepts of English for Academic Purposes. New York: Palgrave Macmillan; 2015.

5.Cambridge Assessment English. Assessing Writing Performance - Level B2. Cambridge:
Cambridge University Press; 2016. https://www.cambridgeenglish.org/Images/cambridgeenglish-assessing-writing-performance-at-level-b2.pdf 6.Coffin C., Curry M.J., Goodman S., Hewings A., Lillis T.M., Swann J. Teaching Academic Writing: A Toolkit for Higher Education . London and New York: Routledge; 2003.

7.Cohen L., Manion L., Morrison K., Wyse D. A Guide to Teaching Practice. Revised $5^{\text {th }}$ ed. New York: Routledge; 2010.

8.Coombe C., Folse K., Hubley N. A Practical Guide to Assessing English Language Learners. Michigan: The University of Michigan Press; 2010.

9.De Chazal E. English for Academic Purposes. Oxford: Oxford University Press; 2014.

10.Fulcher G., Davidson F. Language Testing and Assessment: An Advanced Resource Book. New York: Routledge; 2007.

11.Jamieson J.; Hinkel, E. editors. Assessment of Classroom Language Learning. New York and London: Routledge; 2011.

12.Katz A.; Celce-Murcia M., Brinton D.M., Show M.A. editors. Assessment in Second Language Classrooms. $4^{\text {th }}$ ed. Boston: National Geographic Learning; 2014.

13.Nicholls, G. Developing Teaching and Learning in Higher Education. London: RoutladgeFalmer; 2002.

14.Reece I., Walker S. Teaching, Training and Learning. $4^{\text {th }}$ ed. Sunderland: Business Education Publishers Ltd.; 2002.

15.Weir C.J. Language Testing and Validation: An Evidence-based Approach. London: Palgrave Macmillan; 2005.

\title{
STUDENTS ATTITUDES TOWARD ONLINE LEARNING OF CLINICAL SKILLS DURING COVID
} 19: CHALLENGES AND RESPONSES

Irma Manjavidze ${ }^{1}$

MD, PhD, Full Professor,

Department of Clinical Skills and Multidisciplinary Simulation, Tbilisi State Medical University, Tbilisi, Georgia

Dali Chitaishvili ${ }^{1}$

MD, PhD, Assistant Professor,

Department of Clinical Skills and Multidisciplinary Simulation, Tbilisi State Medical University, Tbilisi, Georgia

Pirdara Nozadze ${ }^{2}$

MD, PhD, Associate Professor,

Department of Clinical Skills and Multidisciplinary Simulation, Tbilisi State Medical University, Tbilisi, Georgia DOI: $10.31618 /$ ESU.2413-9335.2020.7.76.948

\section{ABSTRACT}

Covid 19 posed great challenges to the medical education system around the world. Because of restrictions the Department of Clinical Skills and Multidisciplinary Simulation of Tbilisi State Medical University (TSMU) had to start teaching Clinical Skills using Online Learning Format trying to maintain the basic principles and structure of Peyton's 4-steps approach. The aim of our survey was to evaluate the students attitude to the Online Course of "Clinical Skills 3 “.

\section{АННОТАЦИЯ}

Covid 19 создал большие проблемы для системы медицинского образования во всем мире. Из-за ограничений Департаменту Клинических Навыков и Мультидисциплинарной Симуляции Тбилисского Государственного Медицинского Университета (ТГМУ) пришлось перейти на онлайн-формат обучения, пытаясь сохранить основные принципы и структуру 4-ступенчатого подхода Пейтона. Целью нашего исследование было оценка отношения студентов к онлайн-курсу "Клинические навыки 3 ". 
Key words: distance learning, clinical skills, Peyton's 4 steps approach, feedback questionnaire, Likert scale, student's satisfaction.

Ключевые слова: онлайн обучение, клинические навыки, 4 ступенчатый подход Пейтона, анкета обратной связи, шкала Лайкерта, удовлетворенность студентов.

\section{INTRODUCTION}

Covid 19 posed great challenges to the education system around the world. Institutions and organizations made efforts to rapidly adapt to the increasingly required "social distancing" (1) and Georgia was no exception, where timely measures were taken for the transition of educational institutions to an online learning regime. Tbilisi State Medical University (TSMU) was one of the first to start the spring semester considering these new circumstances.

Department of Clinical Skills and Multidisciplinary Simulation of TSMU offers compulsory courses for 2nd, 4th and 6th year students of Faculty of Medicine, namely -"Clinical Skills 1", "Clinical Skills 3" and "Clinical Skills 4" respectively. Peyton's 4-Steps-Approach is an already proven, effective scheme for the study of clinical skills, which has shown an advantage over other approaches $(2,3,4)$. It consists of four clearly defined instructional steps:

Step 1 - "DEMONSTRATION": The teacher demonstrates the skill at a normal pace and without any comments.

Step 2 - "DECONSTRUCTION / DISCUSSION ": The teacher demonstrates the procedure once more, this time describing each procedural substep in detail.

Step 3 - "COMPREHENSION" : The teacher performs the skill for a third time, based on the substeps described to him by the student. I.e. the teacher follows the student's instructions.

Step 4 - "PERFORMANCE/ EXECUTION": The student performs the complete skill himself on his own.

Our department use slightly modified Peyton approach, namely we have a 5-10 minute power point presentation on the subject during the first step, and during the 4th step students are given time to work independently on manikins and simulators and then each student is evaluated by teacher. Our modified Peyton's approach, which is applied during our face to face classes, is the following:

Step 1 - "DEMONSTRATION": The teacher foreword to the topic (using PPT) and demonstration of the skill at a normal pace and without any comments.

Step 2 - "DECONSTRUCTION / DISCUSSION ": Demonstration of the the procedure by teacher for a second time, this time describing each procedural substep in detail.

Step 3 - "COMPREHENSION" : Demonstration of the the procedure by teacher for a third time, based on the student's instructions .

Step 4 -“ PERFORMANCE / EXECUTION”: Student performs the complete skill several times on his own and at the end of the class is evaluated by teacher.

Due to Covid-19, to limit its spread through social distancing, in-person learning was banned and we had been forced to switch to distance teaching of clinical skills using online meeting platforms $(5,6)$. So like other universities around the world $(1,4)$, we also had to adapt our face to face training course considering current pandemic reality and simultaneously preserving the basic principles and structure of our lessons. It was not easy due to their hands-on nature and online course had to be prepared in a very short time. The TSMU made a great effort to start the Online Learning Format, at the same time the technical staff of the department had assisted the academic staff in the transition to distance learning. Academic staff added more videos to our existing bank of video tutorials (some of them were filmed in our department). As the Remote Online Format is quite new we held online meetings and outlined key principles of remote training, conducted pilot simulation sessions with active participation of the technical staff of our department. The technical team of the department ensured the technical support to teachers and students during the whole semester.

Adaption of all components of clinical skills teaching to Online Learning Format was easily achievable, except for one key component - which involves performance of the practical manipulation by the student himself. In other words, the fourth step had to be replaced by something else. Therefore, we collected questions that would allow students to repeat the learned material, outlining key details. So we changed the existing structure of our lesson using Zoom's online video conferencing platform as follows:

Step 1 - "DEMONSTRATION": Teacher presents PPT, which is introduction to the topic and demonstrates video tutorial at a normal pace without any comments.

Step 2 - "DECONSTRUCTION / DISCUSSION ": The teacher once again demonstrates the procedure using video, pausing the video and detailing each procedural sub-step.

Step 3 - "COMPREHENSION" : The teacher demonstrates the procedure for the third time using video, and one of the student describes one sub-step of the procedure (by the end of the lesson each student has to describe one of the steps of the procedure)

Step 4 - REPETITION \& SUMMARIZATION: Each student in the group has to answer several questions.

The course of "Clinical Skills -3 " for $4^{\text {th }}$ year students covers the following topics (one topic per day): Communication, Lung Auscultation, Heart Auscultation, Intrauterine Device insertion technique, Forceps Delivery, Gynecological examination with Pap test, Newborn Examination, NG intubation/Catheterization, Newborn Resuscitation.

At the end of our online course all $4^{\text {th }}$ year students were asked to evaluate the course using our feedback questionnaire.

\section{OBJECTIVE}

The aim of our study was to evaluate how students at Tbilisi State Medical University evaluate Clinical Skills Course, which took place in remote mode.

\section{METHODS}


According to the curriculum, 12 groups of $4^{\text {th }}$ year students ( $n=136)$ of International Faculty of Medicine had our course in the spring semester of the 2019-2020 academic year. Due to COVID -19 pandemic we tried to be not so strict with our students in daily assessment, but at the same time be fair and objective. So all students who attended online classes, did not refuse to participate in discussions, tried to answer questions and commented on the videos were given maximal marks. So $73,5 \%$ of students (100 out of 136 ) got 60 points that is maximal possible grade before final exam.

Their final exam in distance course of "Clinical Skills 3" was held in a form of the Multiple Choice Question (MCQ) test, which took place on the last day of the course. The test consisted of 40 questions. They had to select one answer from the four proposed answers. The MCQ covered the whole course, namely the above-mentioned topics. Total number of possible points $=1 \mathrm{X} 40=40$ points. $(1$ point per question $)$. They had to answer at least 24 questions correctly out of a total of 40 to pass the exam. We used Survey Monkey platform for our final quiz. All of the students passed the final exam and successfully completed the course. Only one student failed a course due to nonattendance.

At the end of the final exam the link address of the feedback questionnaire was post in our chat. All $4^{\text {th }}$ year medical students were asked to participate in the study, namely to complete questionnaire, which evaluate our course.

\section{RESULTS}

117 students (86\%) completed our questionnaire. (Table 1.) 10 statements were used to measure their attitudes. In statements 1-8 the format of a typical fivelevel Likert scale, ranging from 1 to 5 (from "strongly disagree $=1$ point" to strongly agree" $=5$ points) were used.

Table 1.

Feedback Questionnaire

\begin{tabular}{|l|l|l|l|l|l|}
\hline Question & $\begin{array}{l}\text { Strongly } \\
\text { disagree }\end{array}$ & Disagree & Neutral & Agree & $\begin{array}{l}\text { Strongly } \\
\text { agree }\end{array}$ \\
\hline $\begin{array}{l}\text { 1.The Course of "Clinical Skills" is important for } \\
\text { my future profession. }\end{array}$ & & & & & \\
\hline $\begin{array}{l}\text { 2.I have learned/discussed some clinical cases, } \\
\text { procedures and manipulation within this distance } \\
\text { learning course. }\end{array}$ & & & & & \\
\hline $\begin{array}{l}\text { 3.The proposed scheme of students' work during } \\
\text { distance learning sessions was acceptable. }\end{array}$ & & & & & \\
\hline $\begin{array}{l}\text { 4.The teacher helped to analyze and study the } \\
\text { learning material. }\end{array}$ & & & & & \\
\hline 5.There was enough time for the session. & & & & \\
\hline 6.The webpage of the centre was useful. & & & & \\
\hline $\begin{array}{l}\text { 7.The course material (ppt and videos )was } \\
\text { appropriate for learning. }\end{array}$ & & & & & \\
\hline 8.The grading of the course was fair & & & & \\
\hline $\begin{array}{l}\text { 9.How would you rate the quality of this training } \\
\text { course }\end{array}$ & 12345678910 & & \\
\hline $\begin{array}{l}\text { 10.Please provide any comments or suggestions } \\
\text { that might help to improve this course in the } \\
\text { future. }\end{array}$ & & & & & \\
\hline
\end{tabular}

Students were informed that all data obtained would be treated anonymously. They were informed that the purpose of the study was to evaluate our academic partnership and that their answers would aid in improving the quality of our academic activities in case of remote mode learning.

According to answers $94,8 \%$ of our respondents think that the course is important for their future profession (table 2). The second question asked the participants of the study if they have learned some clinical cases, procedures and manipulation within the distance learning course. $76,9 \%$ of students agree or strongly agree with that statement. More than half of the respondents $(56,4 \%)$ think that the proposed scheme of students' work during distance learning sessions was acceptable.

With fourth statement we wanted to find out if the teachers helped to analyze and study the learning material. Great majority of students $(92,3 \%)$ agree or strongly agree with this statement, only $1,7 \%$ of survey participants disagree or strongly disagree with this statement and nearly $5,9 \%$ are neutral with this point of view.

Students think that there was enough time for the session $(87,2 \%)$.

With statement \#6 we found out that the webpage of the centre was useful for the majority of students $(84,6 \%)$.

Next consideration was about learning materials (videos, ppts). According to our survey $88 \%$ of students affirm the course material was appropriate for learning. With statement \#8, we tried to investigate if the grading of the course was fair. The percentage score for this statement was 4,4 . 
Questionnaire items (1-8) and students evaluation ratings.

\begin{tabular}{|l|l|l|l|l|l|l|}
\hline Q\# & $\begin{array}{l}\text { Strongly } \\
\text { disagree }\end{array}$ & Disagree & Neutral & Agree & $\begin{array}{l}\text { Strongly } \\
\text { agree }\end{array}$ & p/n \\
\hline 1. & $3(2,6 \%)$ & 0 & $3(2,6 \%)$ & $28(23,9 \%)$ & $83(70,9 \%)$ & 4,6 \\
\hline 2. & $2(1,7 \%)$ & $2(1,7 \%)$ & $23(19,6 \%)$ & $64(54,7 \%)$ & $26(22,2 \%)$ & 3,9 \\
\hline 3. & $3(2,6 \%)$ & $7(5,9 \%)$ & $41(35,0 \%)$ & $47(40,2 \%)$ & $19(16,2 \%)$ & 3,6 \\
\hline 4. & $2(1,7 \%)$ & 0 & $7(5,9 \%)$ & $42(35,9 \%)$ & $66(56,4 \%)$ & 4,5 \\
\hline 5. & $2(1,7 \%)$ & $3(2,6 \%)$ & $10(8,5 \%)$ & $53(45,3 \%)$ & $49(41,9 \%)$ & 4,2 \\
\hline 6. & $2(1,7 \%)$ & $2(1,7 \%)$ & $14(11,9 \%)$ & $53(45,3 \%)$ & $46(39,3 \%)$ & 4,1 \\
\hline 7. & $3(2,6 \%)$ & $1(0,85 \%)$ & $10(8,5 \%)$ & $54(46,1 \%)$ & $49(41,9 \%)$ & 4,2 \\
\hline 8. & $2(1,7 \%)$ & $2(1,7 \%)$ & $7(5,9 \%)$ & $46(39,3 \%)$ & $60(51,3 \%)$ & 4,4 \\
\hline
\end{tabular}

By $9^{\text {th }}$ item of the questionnaire students were average point given to our course was 8,49 points (min asked to rate the quality of the training course. The 4, max 10, mode 9) (Diagram 1).

How students rank the training course using 1-10 rating scale.

Diagram 1

\section{How would you rate the quality of this training course \\ 38}

30

$(25,6 \%)$

13

$(11,1 \%)$

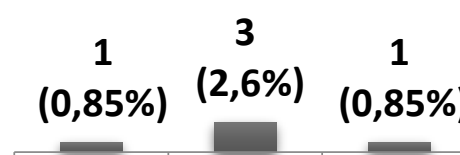

3

$(2,6 \%)$
$(32,5 \%)$

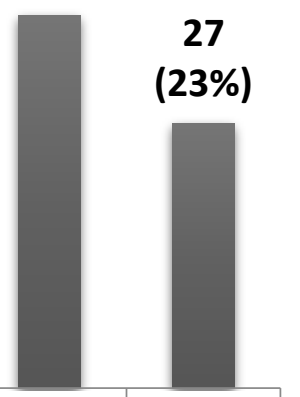

2 points 4 points 5 points 6 points 7 points 8 points 9 points 10 points

By the last statement of the questionnaire students were asked to provide any comments or suggestions that might help to improve the course in the future. 81,9 $\%$ of students gave positive evaluation to our course and they wrote that "it was a good experience" and that "the course was very useful", "everything was perfect". 21 comments were considered as negative or neutral, examples: "need more practical" "no suggestions", "no comments" "nothing".

Though student comments were positive in great majority of cases, some of them wrote that it would be better to practice clinical skills "face-to-face." We informed them that, as soon as it will be possible, our department plans to draw up a schedule according to which students will be able to come to our center to practice all manipulations and procedures that they had learned during the online classes.

Analyzing the feedback of our students, we were very pleased that most students understood the current situation and thanked us for our efforts, although they noted in their comments that real clinical demonstrations is optimal. Most of them wrote that they hope that they will have the opportunity to practice the learned skills in real mode here some of examples:
"I would have preferred to attend classes in real life especially the practical procedures. But nevertheless it was very informative." "If possible we would wish to do the procedure practice so that it will be in mind forever.....course was really good." II wish these classes are better in person to person instead of online sessions. Since we have a very good faculty, we would be happy to have clinical skills as soon as we were there in Tbilisi. "

\section{CONCLUSION}

Thus, we can conclude that in general, students were satisfied with the course, appreciated the contribution and efforts of the Department, are pleased that they have been able to learn the necessary manipulations and procedures at least in this format, as it was optimal in the current situation to minimize risks.

We all hope that the fourth step of the Peyton approach will be implemented in the nearest future, but considering a new reality novel ways of online teaching should be considered in new medical curricula development $(5,6)$, more studies should be conducted to see how to improve the quality of distance learning and further develop online teaching methodology, 
assimilate online teaching pedagogies, to adjust the latest technologies to online education.

\section{REFERENCES}

Noah A. Newman, BS ${ }^{1}$ and Omar M. Lattouf, MD, PHD, FACC, FACS ${ }^{2}$, . Coalition for medical education-A call to action: A proposition to adapt clinical medical education to meet the needs of students and other healthcare learners during COVID 19 J Card Surg. $2020 \quad$ Apr $30 \quad 10.1111$ jocs.14590. doi: 10.1111/jocs.14590 [Epub ahead of print]; PMCID: PMC7267341 PMID: 32353907

Tobias Münster, ${ }^{1}$ Christoph Stosch, ${ }^{1}$ Nina Hindrichs, ${ }^{1}$ Jeremy Franklin, ${ }^{2}$ and Jan Matthes ${ }^{3}$. Peyton's 4-Steps-Approach in comparison: mediumterm effects on learning external chest compression a plot study. GMS J Med Educ. 2016; 33(4): Doc60. Published online 2016 Aug 15. doiLukas B. Seifert, ${ }^{1}$ Benedikt

Stefanescu, ${ }^{2}$ Robert

Schnurr, ${ }^{1}$ Maria-Christina Sader, ${ }^{1}$ Miriam Ruesseler, ${ }^{3}$ and Jasmina Sterz ${ }^{3}$. Comparing videobased versions of Halsted's 'see one, do one' and Peyton's '4-step approach' for teaching surgical skills: a randomized controlled trial. Hamed Khan. An adaptation of Peyton's 4-stage approach to deliver clinical skills teaching remotely. DOI:https://doi.org/1.15694/mep.2020.000073.1

Published daate:23/04/2020Seymour-Walsh AE, Bell A, Weber A, Smith $T$. Adapting to a new reality: COVID-

19 coronavirus and online education in the health professions..Rural Remote Health. 2020 May;20(2):6000. doi: 10.22605/RRH6000. Epub 2020 May 26.PMID: 32456441 Free PMC article.Preeti Sandhu; Maisie de Wolf . The impact of COVID-19 on the undergraduate medical curriculum. Affiliations expand PMID: 32400298 PMCID: PMC7269089

DOI: 10.1080/10872981.2020.1764740 Free PMC article.

Choi B, Jegatheeswaran L, Minocha A, Alhilani M, Nakhoul M, Mutengesa E The impact of the COVID-19 pandemic on final year medical students in the United Kingdom: a national survey. BMC Med Educ. 2020 Jun 29;20(1):206. doi: 10.1186/s12909-020-02117-1.PMID: 32600460 Free PMC article.

\section{ТРЕБОВАНИЯ К РАЗРАБОТКЕ ОБРАЗОВАТЕЛЬНОГО КОНТЕНТА ДЛЯ ДИСТАНЦИОННОГО ОБУЧЕНИЯ СТУДЕНТОВ С ИНВАЛИДНОСТЬЮ}

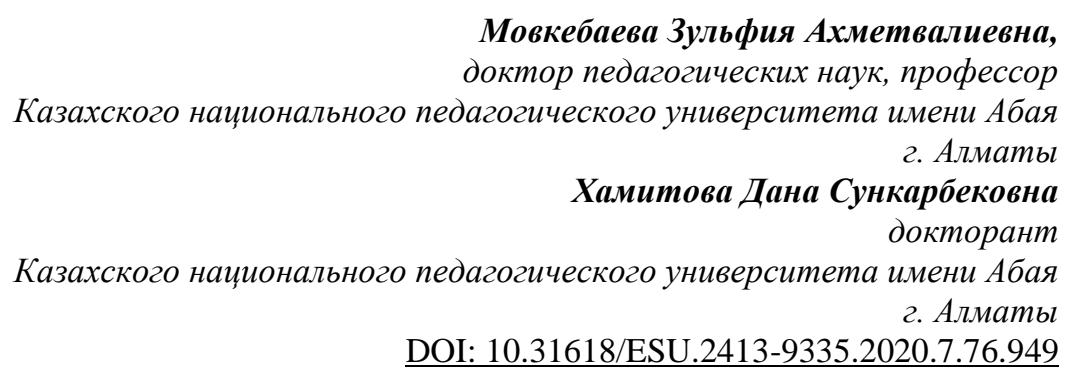

\section{АННОТАЦИЯ}

В данной статье рассматриваются современные подходы к организации дистанционного обучения студентов с инвалидностью в вузе. Определены положительные стороны данной системы и выделены некоторые риски, обуславливающие снижение эффективности обучения студентов с инвалидностью в вузах. основные составляющие системы дистанционного обучения. Описаны необходимые условия и педагогические принципы дистанционного обучения студентов с инвалидностью, базовые требования к подбору материала для лекционных и практических (семинарских) занятий со студентами с различными нарушениями в развитии.

\section{ANNOTATION}

This article discusses modern approaches to the organization of distance learning for students with disabilities in higher education. The positive aspects of this system are identified and some risks that cause a decrease in the effectiveness of teaching students with disabilities in higher education institutions are highlighted. the main components of the distance learning system. It describes the necessary conditions and pedagogical principles of distance learning for students with disabilities, the basic requirements for the selection of material for lectures and practical (seminar) classes with students with various developmental disabilities

Ключевые слова: дистанционное обучение, высшее образование, студенты-инвалиды, особые образовательные потребности, нарушения в развитии.

Keywords: distance learning, higher education, students with disabilities, special educational needs, developmental disabilities

\section{Введение.}

Развитие дистанционного обучения на современном этапе, особенно активно распространяющегося в условиях пандемии коронавируса (COVID-19), обусловило появление определенных рисков снижения качества высшего профессионального образования для людей с особыми образовательными потребностями и в связи с этим актуализировало необходимость совершенствования системы дистанционного образования. Наряду со сложностями технического порядка, перед преподавателями вузов особенно 